\title{
The interaction of water with archaeological and ethnographic birch bark and its effects on swelling, shrinkage and deformations
}

Johanna Klügl ${ }^{1,2^{*}}$ and Giovanna Di Pietro ${ }^{1}$

\begin{abstract}
The aim of this study is to gain specific information on the water vapour interaction with archaeological and ethnographic birch bark. Water is involved in a number of curative and preventive conservation measurements e.g. when re-shaping or drying objects and when defining climate directives for long-term storage. We measured the sorption isotherm of archaeological, ethnographic and contemporary birch bark at different temperatures and analysed the moisture-induced size and shape changes (swelling, shrinkage, deformation) during humidification and drying. The analysis revealed that, compared to other organic materials like wood, the moisture uptake of outer birch bark is modest. This can be attributed to the cell structure and composition: outer birch bark is composed of closed cells made to a large extent of hydrophobic components (suberin, lignin). The equilibrium moisture content is higher if lenticels or inner bark are present. The extent of brittleness and delamination of the sample influences the sorption behaviour: the less brittle and delaminated archaeological birch bark is, the lower the equilibrium moisture content (EMC). Since the moisture uptake is modest, the related swelling of the outer bark is also modest, but anisotropic due to the cellular arrangement. Swelling is largest in the radial direction, smaller in longitudinal and negligible in tangential direction. Water vapour can plasticize birch bark and as birch bark becomes flexible, it bends towards the outside of the bark. This deformation takes place at high moisture contents and the adsorption process is slow. Based on these results recommendations on how best to perform treatments involving moisture and on relative humidity ranges for birch bark objects are provided.
\end{abstract}

Keywords: Birch bark, Cork, Archaeology, Conservation, Sorption, Drying, Deformation, Wet organic objects

\section{Conservation relevance}

Birch bark is a naturally water-repellent organic material used for containers, fishing equipment and mats from Neolithic times until nowadays by indigenous and hunter-gatherer populations.

Objects are in a perishable condition when found wet $[1,2]$ and are often misshapen [3-6] due to an inbuilt tension of the material $[7,8]$. They might also show delamination and increased brittleness $[1,9,10]$. In order to preserve the artefacts preventive and curative

\footnotetext{
*Correspondence: johanna.kluegl@be.ch

1 Bern University of the Arts, Fellerstrasse 11, 3027 Bern, Switzerland

Full list of author information is available at the end of the article
}

conservation is needed. Preventive conservation involves the setting of relative humidity targets to avoid deformations, mould growth and chemical degradation. Curative treatments involve water in a number of cases. Birch bark objects may be humidified with water vapor at room or higher temperature in order to soften them during reshaping [7]. They might also be frozen for short-term preservation or dried with [2] and without a pre-consolidation [11]. Drying is performed with a general hesitation as it known to cause shrinkage and distortion in waterlogged wooden objects [12, 13]. How far birch bark objects might swell, shrink and deform is expected to depend on the amount of moisture absorbed by the bark and on its preservation condition, namely brittleness and delamination. The amount of moisture absorbed
Springer Open

(c) The Author(s) 2021. This article is licensed under a Creative Commons Attribution 4.0 International License, which permits use, sharing, adaptation, distribution and reproduction in any medium or format, as long as you give appropriate credit to the original author(s) and the source, provide a link to the Creative Commons licence, and indicate if changes were made. The images or other third party material in this article are included in the article's Creative Commons licence, unless indicated otherwise in a credit line to the material. If material is not included in the article's Creative Commons licence and your intended use is not permitted by statutory regulation or exceeds the permitted use, you will need to obtain permission directly from the copyright holder. To view a copy of this licence, visit http://creativeco mmons.org/licenses/by/4.0/. The Creative Commons Public Domain Dedication waiver (http://creativecommons.org/publicdomain/ zero/1.0/) applies to the data made available in this article, unless otherwise stated in a credit line to the data. 
or released by the bark is characterized by the sorption isotherm being the equilibrium moisture content (EMC) at different humidity values and constant temperature. The sorption isotherm of birch bark has been measured on freshly harvested samples but never on archaeological samples. Furthermore, the swelling, shrinkage and deformation of outer birch bark during wetting and drying has never been published. In this article we fill this gap by presenting first measurements of sorption isotherms as well as swelling and shrinkage of birch bark on a number of archaeological and ethnographic samples.

\section{The material birch bark: macroscopic and microscopic structure and chemical composition}

The portion of birch bark used to manufacture objects is the outer bark, in botany called the phellem layer, in plain language cork. The phellem prevents the birch tree from transpiration, it isolates it from heat, sun-radiation and cold [14] and protects it from the penetration of parasites [15]. Both chemical composition and phellem anatomy determine the moisture adsorption properties.

\section{Phellem}

The phellem is made of cells formed each year from May to August [16] by a thin layer of active cells, the phellogen or cork cambium, present between the inner and the outer bark (Fig. 1). Cells in the phellem are organized in bands of thin-walled cells and thick-walled cells that differ in the filling material of the cell lumen (Fig. 2, b and c). Both thick-walled and thin-walled cell walls contain suberin, a biopolymer made of polyaliphatic and polyphenolic parts connected by glycerol via ester bonds. As a consequence of the suberization of the cell walls these become impermeable and the cells die. Suberin makes $36.2 \mathrm{wt} \%$ of the phellem total composition and together with the closed structure of the cells is responsible for the low water permeability of the phellem [17]. Lignin accounts for $14.3 \mathrm{wt} \%$ of the phellem composition and is found in the middle lamella and between the suberin molecules in the secondary cell walls [18] (Fig. 2c). Polysaccharides account for $10.3 \mathrm{wt} \%$ of the phellem composition while extractives accounts for $32.2 \mathrm{wt} \%$ and are located in the cell lumen [19]. In particular the thinwalled cells are filled with betulin, a triterpene, while the thick-walled cells are filled with phenolic components.

The number of cell layers in each band depends on the phellem age and on the species. The freshly formed phellem cells are pushed against the existing layers and, as the tree circumference grows, they are pushed outwards, stretched in the tangential direction and compressed in the radial direction (Figs. 2b, 3) [7, 8] and eventually come off the tree. Both phellem thickness [20] and stiffness [21] increase with age: the thickest outer bark can be found on the bottom of a tree. Generally, birch bark objects are made only from the phellem layer, as this can be easily removed from the trunk when the bark is harvested in spring and summer, the time when the phellogen is active. In this case the phelloderm and the phloem remain attached to the trunk (Fig. 4). Only if the bark is

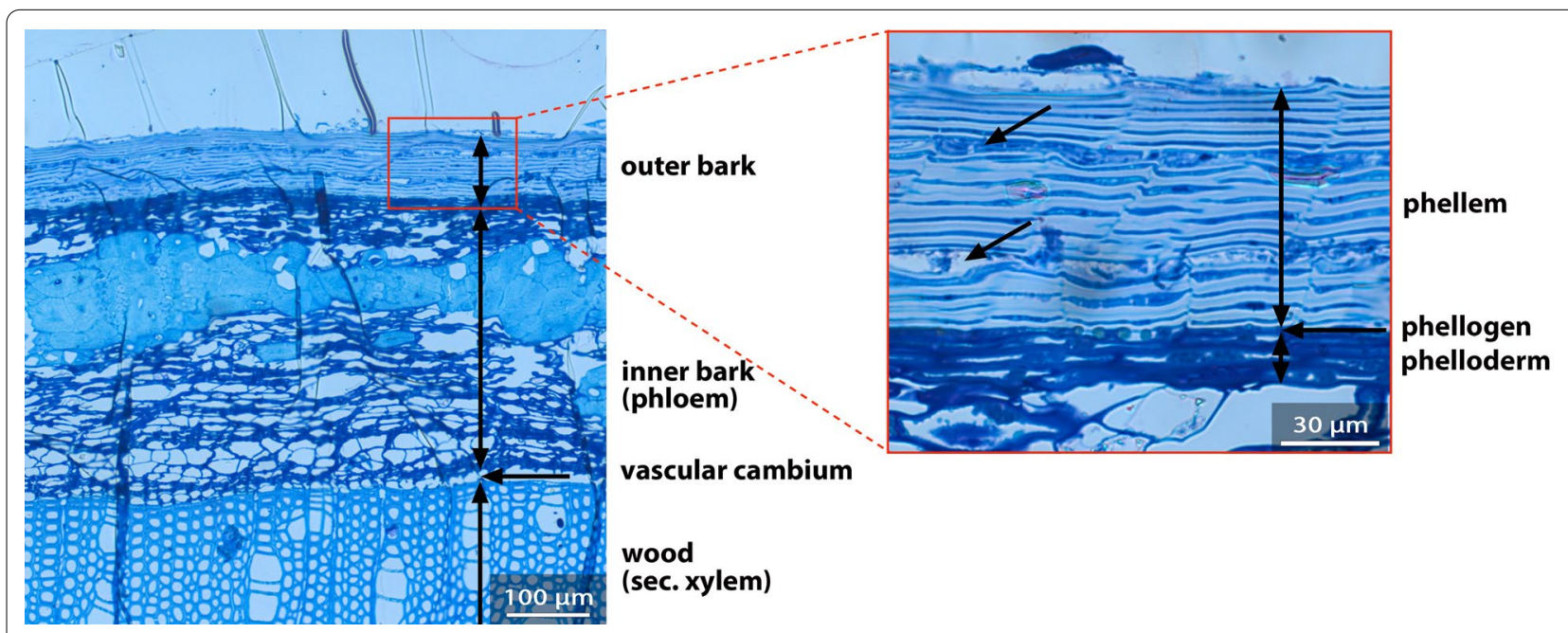

Fig. 1 Cross-section of a 5 year old birch twig $(L M, 10 x)$, stained with an aqueous solution of $0.5 \%$ toluidine blue $\mathrm{O}(\mathrm{w} / \mathrm{v})$. a shows the inner and the outer bark, the vascular cambium and the xylem. b Detail of the outer bark (LM, 40x) on the right. The phellogen or cork cambium is responsible for the production of the outer bark cells and of the phelloderm. It produces phelloderm towards the inside, a layer of living non-suberized parenchyma cells and phellem towards the outside, a protective tissue made of dead cells of the same size as the phellogen. In this sample only two layers of thin-walled cells are present (arrows) 


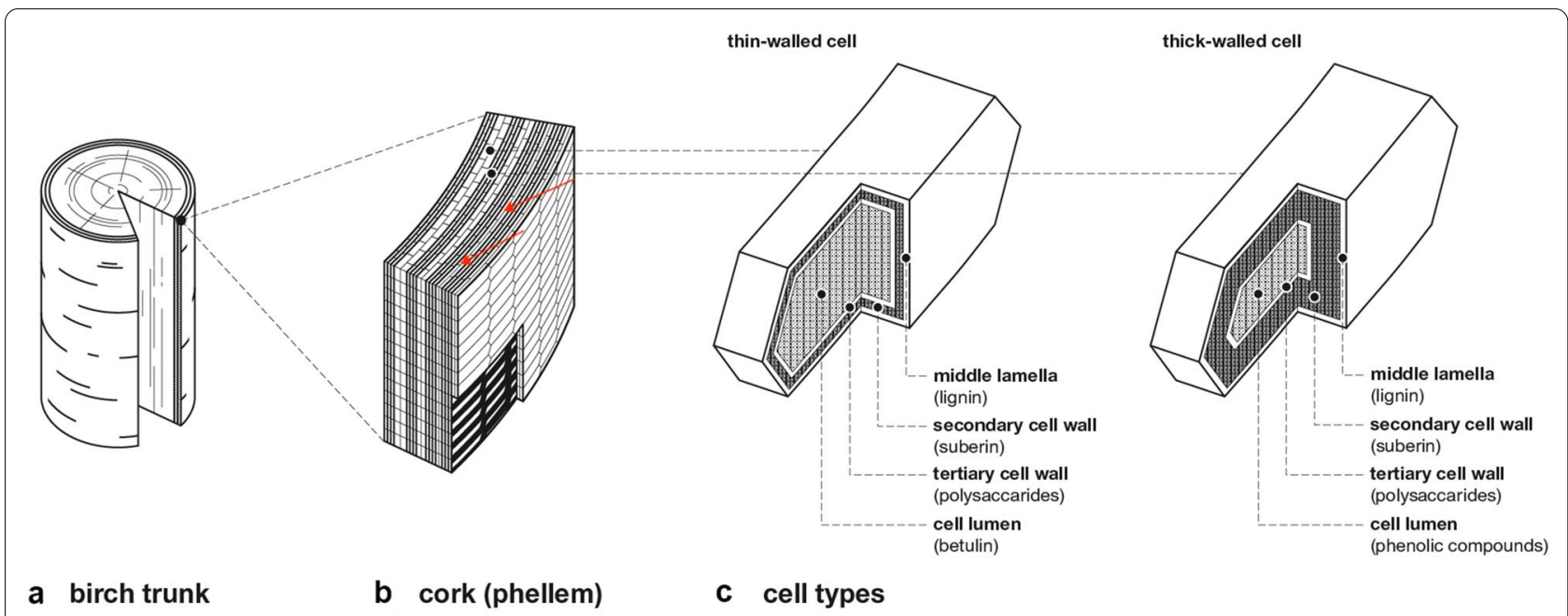

Fig. 2 Betula phellem from a macroscopic to a microscopic scale. a Location of outer bark (phellem) on a birch trunk with typical horizontal lenticels. $\mathbf{b}$ Phellem layer consisting of thin-walled and thick-walled cells. During the growth of the trunk the outer layers are stretched in tangential direction and the thin-walled cells are compressed in radial direction (arrows). c Shape of the two cell-types with main chemical components. Note that they lie perpendicular to the long axis of the tree

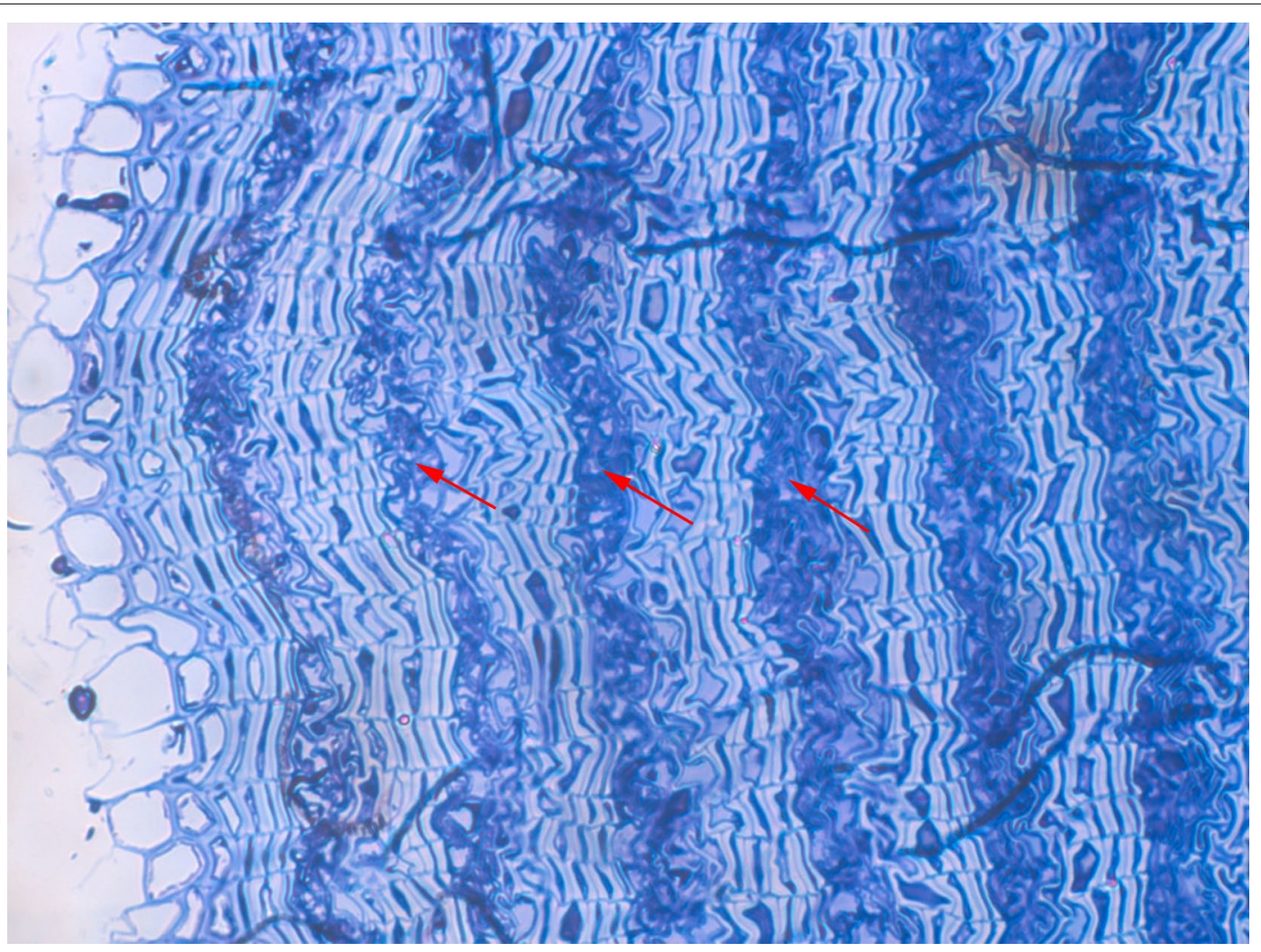

Fig. 3 Radial section of contemporary birch bark harvested from a mature tree, stained with an aqueous solution of $0.5 \%$ toluidine blue $\mathrm{O}(\mathrm{w} / \mathrm{v})$, LM 40x. Newly formed phellem layers are pushed outwards and pressed against existing layers causing folding of the thin-walled radial cell walls (arrows) 


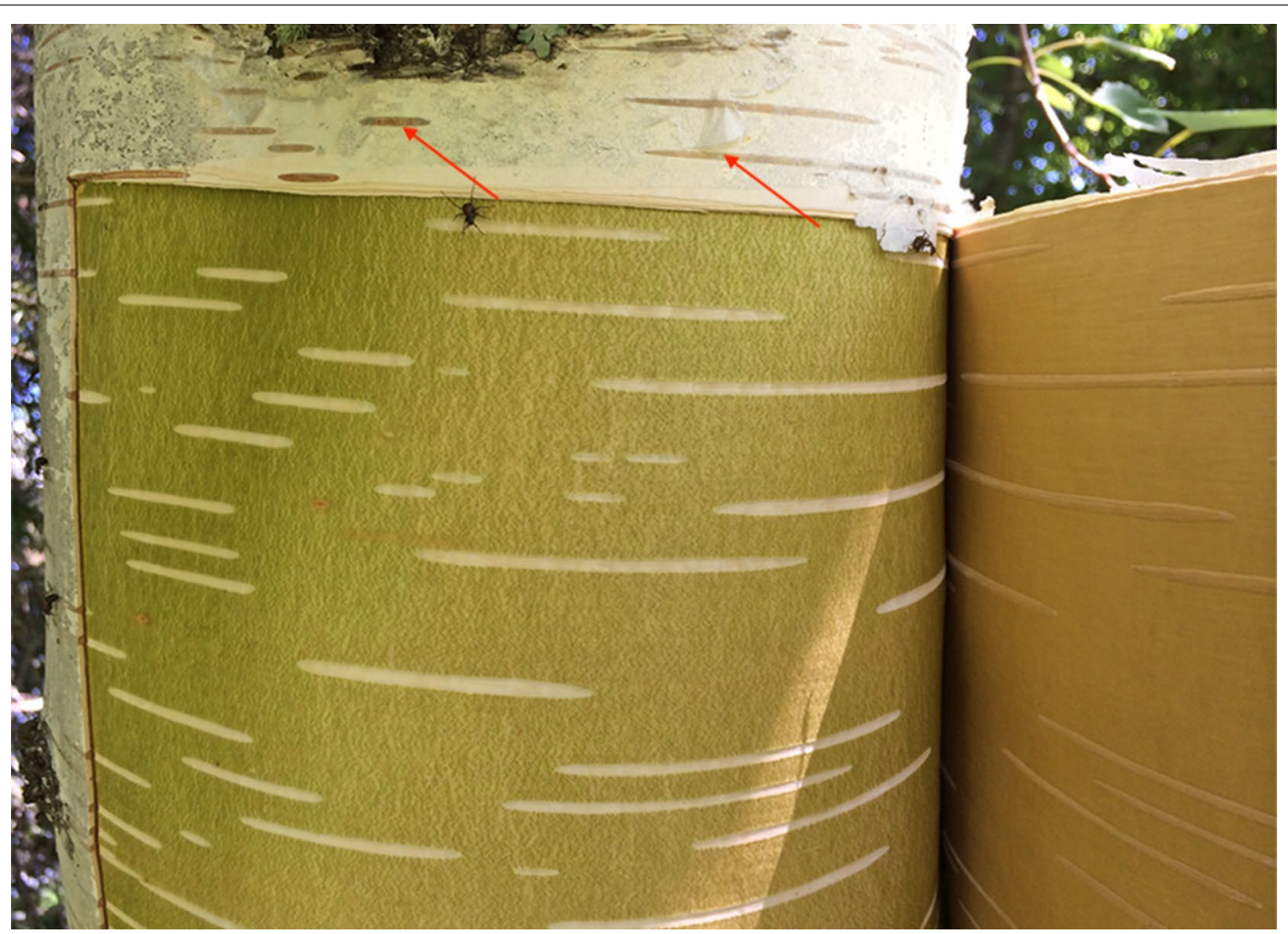

Fig. 4 Harvesting of the bark from a birch tree in summer. On the top the characteristic white outer birch bark (phellem) and the brown horizontal lenticels are visible (arrows). A vertical cut was made on the left to begin the removal of the phellem. The separation of the phellem took place along the phellogen and the green phelloderm stayed on the trunk. The lenticels are visible as impressions on the trunk. The red tone of the inner side of the phellem is visible on the right

harvested in winter will the phelloderm and the phloem stay attached to the phellem. Further, when manufacturing objects, a portion of the white, outermost (oldest) layers of the phellem are usually removed since they are more brittle and more permeable to water and oxygen [22].

\section{Phloem}

The phloem and the phellem differ radically in function, orientation, anatomical structure and chemical composition. The function of the phloem is to transport sugars from the leaves to the roots of the plant, whose constituent parts are therefore mainly aligned in longitudinal direction. It is produced not by the phellogen but rather by the vascular cambium, which builds the phloem outwards and the secondary xylem (wood cells), inwards (Fig. 1). The phloem is a complex tissue consisting of sieve tubes (open cells dedicated to the transport of nutrients), fibres, phloem parenchyma, sclerenchyma and ray parenchyma $[23,24]$. Parenchyma are living thinwalled cells of various functions, sclerenchyma are dead cells with a thick secondary lignified wall with a support function and rays are the continuation of rays of the xylem. The phloem can also produce additional cells. Polysaccharides, such as cellulose constitute $43 \mathrm{wt} \%$ of the phloem chemical composition, lignin $32.2 \mathrm{wt} \%$, suberin $13.2 \mathrm{wt} \%$ and various extractives $8.1 \mathrm{wt} \%$ [19].

Gas and water exchange between the internal tissues of the stem and the environment is allowed through pores in the phellem called lenticels (shown in Fig. 4) that visually characterize the birch bark surface. Lenticels are fanned out bands of cell layers made of continuous bands of thick-walled cells and disrupted bands of thin-walled cells.

\section{Phelloderm}

The phellogen produces phelloderm towards the inside, a layer of living non-suberized parenchyma cells. The phellogen produces phellem towards the outside, a protective tissue made of dead cells of the same size as the phellogen.

\section{Interaction of birch bark with water}

Different authors [24-30] investigated the sorption behaviour of freshly harvested birch bark, mostly in studies on the influence of the addition of bark material to the 
properties of wooden particleboards. Samples where the phloem is still attached to the outer bark are characterized by a high hygroscopicity, similar to wood [28], while samples where only the phellem is retained are characterized by a four times smaller moisture content that has little dependency on the specific birch species. In Fig. 5 the adsorption isotherms are reported. Kajita [30] measured the sorption isotherm at two temperatures, 20 and $30{ }^{\circ} \mathrm{C}$, and confirmed the well-known slight decrease of the EMC by increasing temperature observed in hygroscopic materials. Holmberg et al. [26] measured scanning isotherms in adsorption and desorption for Betula Papyrifera samples. The time needed to reach equilibrium at each step of the sorption isotherm depends on the sample thickness, preparation method and presence of air circulation in the surrounding environment. This study showed that for cuboidal samples with sizes of $\sim 2 \mathrm{~mm}^{3}$ in a ventilated environment EMC is reached in approximately $8 \mathrm{~h}$, where half of the weight loss is attained in the first 30 min during desorption.

An understanding of which component in the phellem adsorbs water is provided by the study of Schönherr and Ziegler [22] on samples of the bark of Betula Pendula Roth. Thin samples of the bark were clamped between two permeability cups filled with a $1 \% \mathrm{AgNO}_{3}$ water solution and infiltrated for $12 \mathrm{~h}$. After exposure, samples were treated with hydrochloric acid to precipitate the silver ions. Electron micrographs of embedded samples revealed silver in the middle lamella and in the primary but not in the secondary, suberized, cell wall. It was significantly more concentrated in the radial middle lamellae than in the tangential. Furthermore, it was found in the lenticels, which have intercellular spaces in the tangential direction. This study shows that the radial middle lamella and the lenticels are the components that mostly adsorb water and build the pathway for the diffusion of water into the phellem.

Moisture adsorption is therefore expected to increase if the phloem is retained on the sample, if the sample contains lenticels, if the number of void spaces increases as it occurs in brittle degraded samples and by decreasing temperature.

The adsorption and desorption of water is expected to cause swelling and shrinkage of birch bark. Gilberg [8] analysed microtome samples of the outer bark of Betula papyrifera Marsh exposed for $24 \mathrm{~h}$ to water vapor and found no radial and tangential swelling, while Groh et al. [25] analysed discs of $1 \mathrm{~cm}$ diameter from the outer bark of Betula potaninii and detected a $4 \%$ increase in surface area when exposed to $100 \% \mathrm{RH}$. Bhat [20] investigated the shrinkage of the inner and outer bark of freshly harvested Betula pendula and Betula pubescens and found that it is anisotropic, being higher in radial than in tangential direction. The same anisotropic behaviour is documented for Douglas fir cork [31] and oak cork [18]. The high radial swelling is attributed by both authors to the unfolding of corrugated lateral walls of thin-walled cells taking place upon moisture adsorption (Fig. 3, arrows). The stretched state of the radial cell walls is retained upon drying while further adsorption of water vapor or liquid water causes a radial expansion of much smaller magnitude [32]. Data is not available on the swelling and shrinkage of outer birch bark for contemporary or for archaeological and ethnographic material.

Besides swelling and shrinkage, water adsorption may lead to bending of the bark. Water acts as a plasticizer allowing the phellem's outermost cells, that in the tree have been stretched tangentially to accommodate the

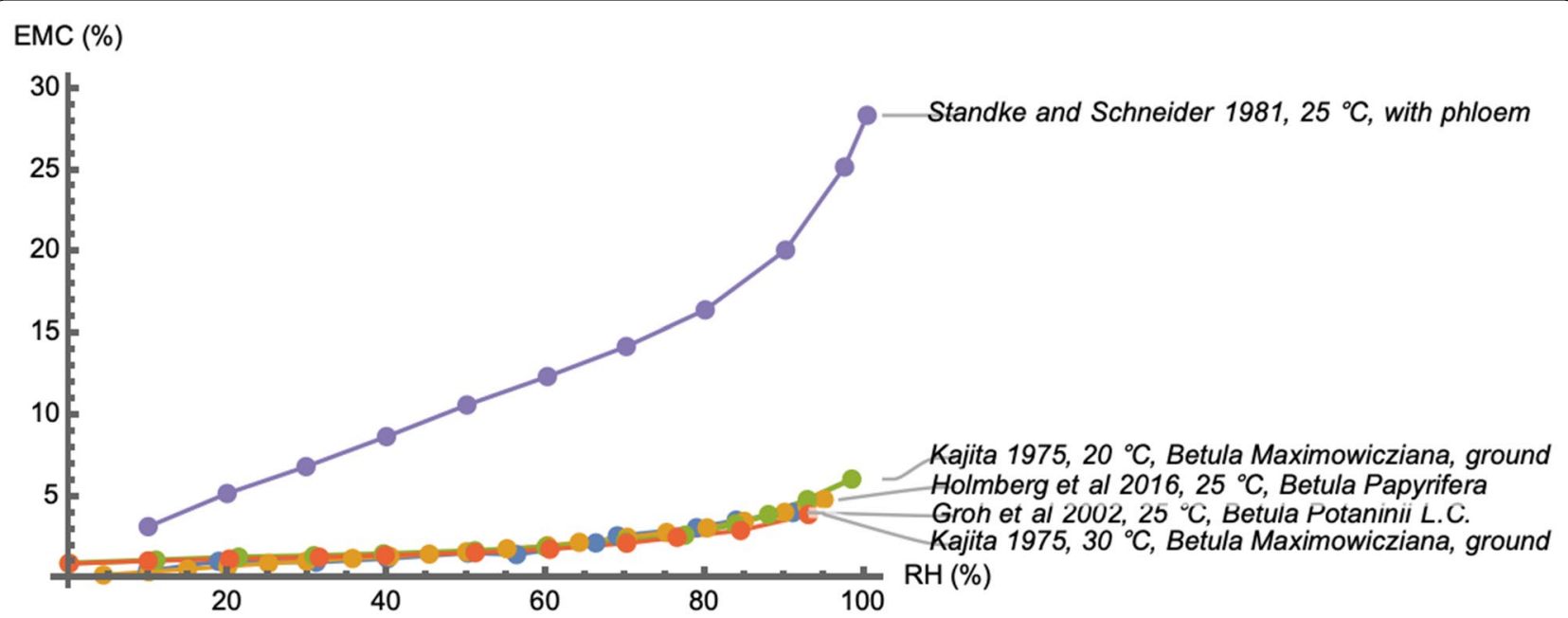

Fig. 5 Sorption isotherms of the bark of different Betula species. Data compiled from references quoted in the bibliography 
growth of the stem and the creation of new layers, to return to their original dimension. This causes a contraction of the outer layer and therefore a bending or rolling of the material with the outer side of the bark inwards [7, 8]. Deformation can also lead to delamination related to failure in the thin-walled cell layers that are intrinsically weaker than the thick-walled cell layers [22, 33]. To avoid such deformation, conservators may block the artefact in the desired shape using specially made capsules during both humidification and drying [11].

The aim of the present research is to quantify equilibrium moisture content, swelling, shrinkage and macroscopic deformation of archaeological and ethnographic birch bark samples upon adsorption and desorption of water vapor in order to provide conservators with indications on the risks related to procedures that involve humidification and drying.

\section{Experimental}

Three types of experiments were performed:

1. Measurement of the EMC at different temperatures $\left(-20,0,25^{\circ} \mathrm{C}\right)$, in relative humidity ranges from 0 to 95\% RH;

2. Measurement of swelling and shrinkage induced by water vapour and observation of the related decay patterns (deformation, cracking, delamination);

3. Simultaneous measurement of deformation by timelapse photography and mass loss during water desorption.

\section{Sample description and preparation}

The water vapour induced changes to outer birch bark were investigated on a contemporary material acting as control sample (WA), an ethnographic material to explore the effect of the phloem $(\mathrm{C})$ and three different archaeological materials recovered from water (B), permafrost $(\mathrm{P})$ and ice $(\mathrm{S})$ to explore the effect of the burial context.

Table 1 reports the characteristics of the materials and the experiments performed with them.

All materials except $C$ and $B$ consisted only of the phellem layer. Material $C$ has remains of the phloem visible as a brown-red layer. This was used to create a flower décor pattern, found typically on artefacts from North America and Siberia. It was not removed before isotherm experiments. Material B was harvested from Neolithic waterlogged birch trunks found in the lake Burgäschi, Switzerland. After vertically sectioning the bark on the trunk, this could carefully be detached and, contrary to what happens with contemporary bark, it remained in its original shape and with phellogen, phelloderm and phloem still adhering. The phloem, characterized by different moisture sorption properties, was removed to allow comparison with the other archaeological materials. The removal was performed mechanically by gently scraping it off with a wooden stick. The enzymatic treatment proposed by Orgell [34] and revised by Schreiber and Schönherr [35] and consisting of immersion in a solution of a fungal pectinase and cellulase was tested but did not lead to the disintegration of the phelloderm within a time period of 4 and half weeks. After the pretreatment, Material B consists of phellem, phellogen and phelloderm and was stored in deionized water and kept refrigerated at $4{ }^{\circ} \mathrm{C}$. Material $\mathrm{S}$ is the Schnidejoch bow case. The cover, middle and lower part of the bow case are considered as three distinct materials as they differ in preservation condition and detailed manufacture characteristics. The bow case cover has been subjected to a harmful treatment with alcohol that extracted most of alcohol soluble components from the bark. It is now stored dry at ambient temperature. The middle and the lower part of the bow case body are untreated (damp), but the lower part is tapered and made of thicker bark. Both of them are stored frozen at $-26^{\circ} \mathrm{C}$. The remaining dry materials are stored at ambient temperature.

The sorption measurements were conducted on samples of size of about $15 \times 5 \mathrm{~mm}$ and with thickness (radial face) in the range $1.3-2.5 \mathrm{~mm}$. Measurement of swelling, shrinkage and deformation (Materials C, P, B) required large samples of length between 80 and $120 \mathrm{~mm}$. Samples taken from material $\mathrm{P}$ showed significant delamination, samples taken from material $C$ and $B$ were bent, for $C$ with the inner side of the bark facing outwards while $\mathrm{B}$ had its inner bark side facing inwards.

\section{Scanning isotherm at $25^{\circ} \mathrm{C}$}

Scanning isotherms at $25^{\circ} \mathrm{C}$ were measured with a multisample gravimetric vapor sorption analyser (SPSx-1 $1 \mu$ Advance) from ProUmid. A drawing and description of the instrument has been published by Murr and Lackner [36]. Before starting the sorption cycle the samples were dried over silica gel to $0 \% \mathrm{RH}$. Then the samples were exposed to increasing relative humidity in $10 \%$ steps from 0 to $95 \%$ at a constant temperature of $25^{\circ} \mathrm{C}$ and weighed every $15 \mathrm{~min}$. If the rate of weight change was smaller than $0.01 \%$ in $80 \mathrm{~min}$, the samples were considered in equilibrium with the relative humidity and the value of the relative humidity was changed. After reaching equilibrium with $95 \%$ the value of the relative humidity was decreased and the desorption cycle was recorded. The full sorption cycle took $600 \mathrm{~h}$. Each type of material was analysed in duplicate; differences in EMCs at the same relative humidity were in all cases less than $0.4 \mathrm{~g} / 100 \mathrm{~g}$. 
Table 1 Description of the materials and of the experiments performed on them

\begin{tabular}{|c|c|c|c|c|c|c|}
\hline $\begin{array}{r}\text { Material } \\
\text { code }\end{array}$ & Origin/species & $\begin{array}{l}\text { Shape/Appearance / } \\
\text { Preservation } \\
\text { Condition }\end{array}$ & Context & Dating & Experiments & Images \\
\hline WA & $\begin{array}{l}\text { felled trunk, Valais } \\
\text { Switzerland, } \\
\text { Betula pendula }\end{array}$ & $\begin{array}{l}\text { Compact, slightly } \\
\text { bent, undecayed } \\
\text { reference material }\end{array}$ & dry & $\begin{array}{l}\text { Contemporar } \\
\text { y (6 years) }\end{array}$ & $\begin{array}{l}\text { sorption } \\
\text { isotherm at } 25 \\
{ }^{\circ} \mathrm{C}\end{array}$ & \\
\hline C & $\begin{array}{l}\text { Container by First } \\
\text { Nations peoples in } \\
\text { Canada, probably } \\
\text { Betula papyrifera }\end{array}$ & $\begin{array}{l}\text { Compact, strongly } \\
\text { bent with the } \\
\text { cambium side out and } \\
\text { remains of the } \\
\text { phelloderm and the } \\
\text { phloem, the material } \\
\text { is stiff but not brittle } \\
\text { and shows slight } \\
\text { delamination }\end{array}$ & dry & $\begin{array}{l}\text { Ethnographic } \\
\text { ( } \approx 40 \text { years) }\end{array}$ & $\begin{array}{l}\text { sorption } \\
\text { isotherm at } 25 \\
{ }^{\circ} \mathrm{C} \text {, swelling, } \\
\text { shrinkage and } \\
\text { deformation }\end{array}$ & \\
\hline $\mathrm{P}$ & $\begin{array}{l}\text { Ceiling of a } \\
\text { tumulus, Pazyryk } \\
\text { culture, Berel, } \\
\text { Altai region, } \\
\text { Republic } \\
\text { Kazakhstan, } \\
\text { excavated in } 2018 \\
\text { in permafrost soil, } \\
\text { probably Betula } \\
\text { pubescens }\end{array}$ & $\begin{array}{l}\text { flat and stable, no } \\
\text { major brittleness but } \\
\text { the material shows a } \\
\text { heavy delamination }\end{array}$ & dry & $\begin{array}{l}5^{\text {th }} \text { to } 3^{\text {rd }} \\
\text { century BC } \\
\text { (Iron age) }\end{array}$ & $\begin{array}{l}\text { sorption } \\
\text { isotherm at } 25 \\
{ }^{\circ} \mathrm{C} \text {, swelling } \\
\text { and shrinkage }\end{array}$ & \\
\hline$B$ & $\begin{array}{l}\text { Trunks from the } \\
\text { lake dwelling site } \\
\text { Burgäschisee } \\
\text { north, } \\
\text { Switzerland, } \\
\text { Cortaillod culture, } \\
\text { excavated in 2017, } \\
\text { probably Betula } \\
\text { pendula }\end{array}$ & $\begin{array}{l}\text { Fragile / bent with } \\
\text { the outer side out } \\
\text { (same orientation as } \\
\text { on the tree), the } \\
\text { material is very brittle } \\
\text { but shows no } \\
\text { delamination }\end{array}$ & $\begin{array}{l}\text { Water- } \\
\text { logged }\end{array}$ & $\begin{array}{l}2800 \text { BC } \\
\text { (Neolithic) }\end{array}$ & $\begin{array}{l}\text { sorption } \\
\text { isotherm at } 25 \\
{ }^{\circ} \mathrm{C} \text {, swelling }\end{array}$ & \\
\hline S cover & $\begin{array}{l}\text { Schnidejoch bow } \\
\text { case cover, } \\
\text { preserved in } \\
\text { alpine ice, species } \\
\text { unknown }\end{array}$ & $\begin{array}{l}\text { Found in } 2003 \text {, in } \\
2008 \text { treated in } \\
\text { several alcohol } \\
\text { solutions, the } \\
\text { material is stiff and } \\
\text { slightly brittle, } \\
\text { delamination is } \\
\text { present }\end{array}$ & dry & $\begin{array}{l}2800 \text { BC } \\
\text { (Neolithic) }\end{array}$ & $\begin{array}{l}\text { sorption } \\
\text { isotherm at } 25 \\
{ }^{\circ} \mathrm{C}\end{array}$ & \\
\hline
\end{tabular}


Table 1 (continued)

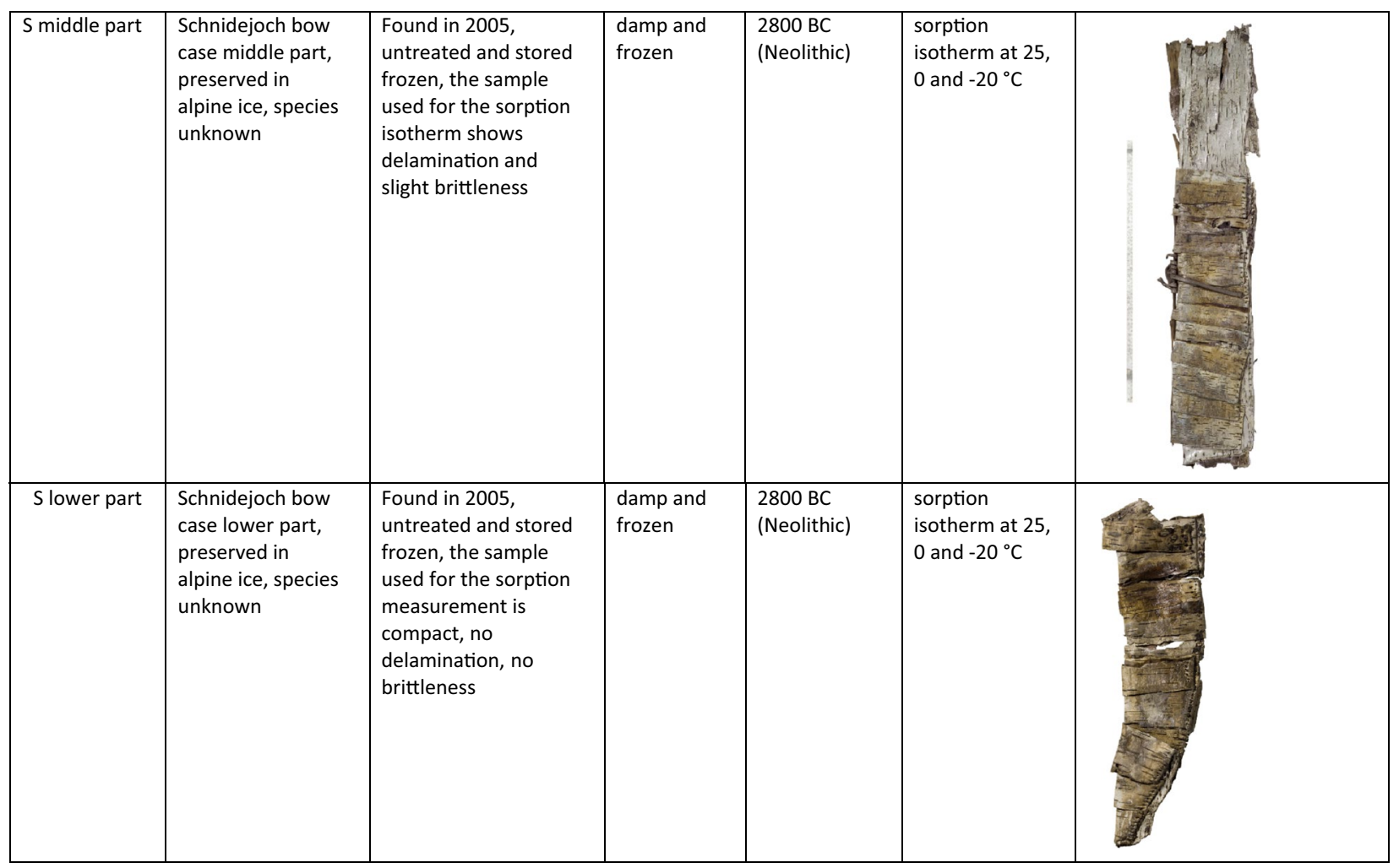

Scanning isotherm at $0{ }^{\circ} \mathrm{C}$ and $-20^{\circ} \mathrm{C}$

Adsorption isotherms at $0{ }^{\circ} \mathrm{C}$ and $-20^{\circ} \mathrm{C}$ were measured on two samples from material S. The measurements were performed at TH Wildau, Germany with a McBain-Bakr balance [37]. In this balance the sample holder is connected to a quartz spring within a quartz tube. The pressure in the tube is controlled by MKS Baratron pressure heads of high sensitivity in the range $10^{-5}$ to $10^{3}$ mbar. The elongation of the spring is measured with a KM6 cathetometer (workshops of the Soviet Academy of Sciences, Moscow) with an accuracy of $\pm 0.01 \mathrm{~mm}$ and a sensitivity of the spring of $0.04 \mathrm{mg} / \mathrm{mm}$. Prior to the adsorption measurements the samples are equilibrated at room temperature in high vacuum atmosphere $\left(p<10^{-}\right.$ ${ }^{5}$ mbar) for at least $12 \mathrm{~h}$ and the dry mass is measured (accuracy $\pm 0.02 \mathrm{mg}$ ). The sample temperature is kept constant during the measurement by a thermostat (Lauda Ecoline RE107) with fluctuations of $\pm 0.05{ }^{\circ} \mathrm{C}$ while the temperature of the spring is maintained at $30{ }^{\circ} \mathrm{C}$ to avoid temperature-related length changes. The equilibrium between the sample and the environment is reached when the pressure and the mass are constant for at least $30 \mathrm{~min}$, which took about $24 \mathrm{~h}$.

\section{Swelling and shrinkage during humidification and drying}

Percentage swelling and shrinkage in the three dimensions was calculated in reference to the dimensions of the samples equilibrated at 50 and $97 \% \mathrm{RH}$. We have decided to use as a reference the $50 \%$ RH condition and not a dryer state as this is the most common condition in repositories. The dimensions in the swollen state were measured after the samples were equilibrated at $97 \% \pm 3 \% \mathrm{RH}$ for 28 days at $4{ }^{\circ} \mathrm{C}$ in a box containing a water saturated polyester fleece separated from the samples with a Tyvek ${ }^{\circledR}$ tissue. The dimensions at $50 \%$ $\mathrm{RH}$ were measured after the samples were equilibrated at $50 \% \pm 3 \% \mathrm{RH}$ for 8 days at $20{ }^{\circ} \mathrm{C}$ in air. For the waterlogged samples taken from material B only shrinkage measurements were performed.

Sample dimensions were measured with a digital calliper with an accuracy of $\pm 0.02 \mathrm{~mm}$ or, where not possible, by scanning the sample on a photocopy machine and analysing the images with the software ImageJ. For each type of sample material, the measurements were performed on four samples and the average and standard deviation were calculated. The samples were also photographed from all sides to assess further changes like cracks and delamination. 


\section{Deformation and mass loss during desorption}

The correlation between deformation during air drying and mass loss was investigated by time-lapse photography of the samples placed on an electronic scale. A sample from material $C$ that was compact and stiff but initially bent as it was cut out from an object, was first conditioned to $97 \% \mathrm{RH}$ at $4{ }^{\circ} \mathrm{C}$ for 4 weeks and then placed at ambient conditions $\left(22^{\circ} \mathrm{C}, 54 \% \mathrm{RH}\right)$ on a Kern EG 600-C3 NM scale with an accuracy of $0.001 \mathrm{~g}$ and photographs of the cross section were taken with a Nikon DC 1500 for $26 \mathrm{~h}$ in total.

\section{Results and discussion}

\section{Scanning isotherms}

Scanning isotherms both in adsorption and desorption modes were measured for all samples confirming the well-known hysteresis effect, whereby the EMC attained through desorption experiments is higher than the one attained at the same relative humidity through adsorption. The diagrams show only the adsorption isotherms as an evaluation of the hysteresis from a not water-saturated starting point can be misleading [38]. The full scanning isotherms are in the Additional file 1, Additional file 2.

The sorption isotherm of the reference material WA (Fig. 6), taken from a contemporary Betula pendula tree, is similar to the sorption isotherms published in the literature (Fig. 5), thus confirming that the sorption behaviour does not depend on the specific birch species.

The influence of the presence of lenticels was investigated on samples from material WA, while the influence of the phloem on samples from material C (Fig. 6).

The EMC increases if the phloem is present on the outer bark, confirming the observations of Standke and Schneider [39]. This increase is related to the different structure and chemical composition of the phloem, as described earlier. The presence of the lenticels also increases the EMC, confirming the observations of Schönherr and Ziegler [22] on water deposition in the lenticels' intercellular cavities.

Figure 7 shows the sorption isotherms at $25{ }^{\circ} \mathrm{C}$ of archaeological samples recovered from different contexts. There is a correlation between the hygroscopicity of the samples and the extent of brittleness and delamination. Extent of brittleness and delamination were evaluated qualitatively based on the number of fragments produced when the samples are sectioned and on the number of separated layers. The more brittle and delaminated the samples are, the higher their EMC, a sign that in brittle and delaminated materials there are more bonding sites for water vapour molecules.

The temperature dependence of the adsorption isotherm was investigated on two samples from the middle part and one sample from the lower part of material $\mathrm{S}$, the Neolithic bow case from the Schnidejoch. The

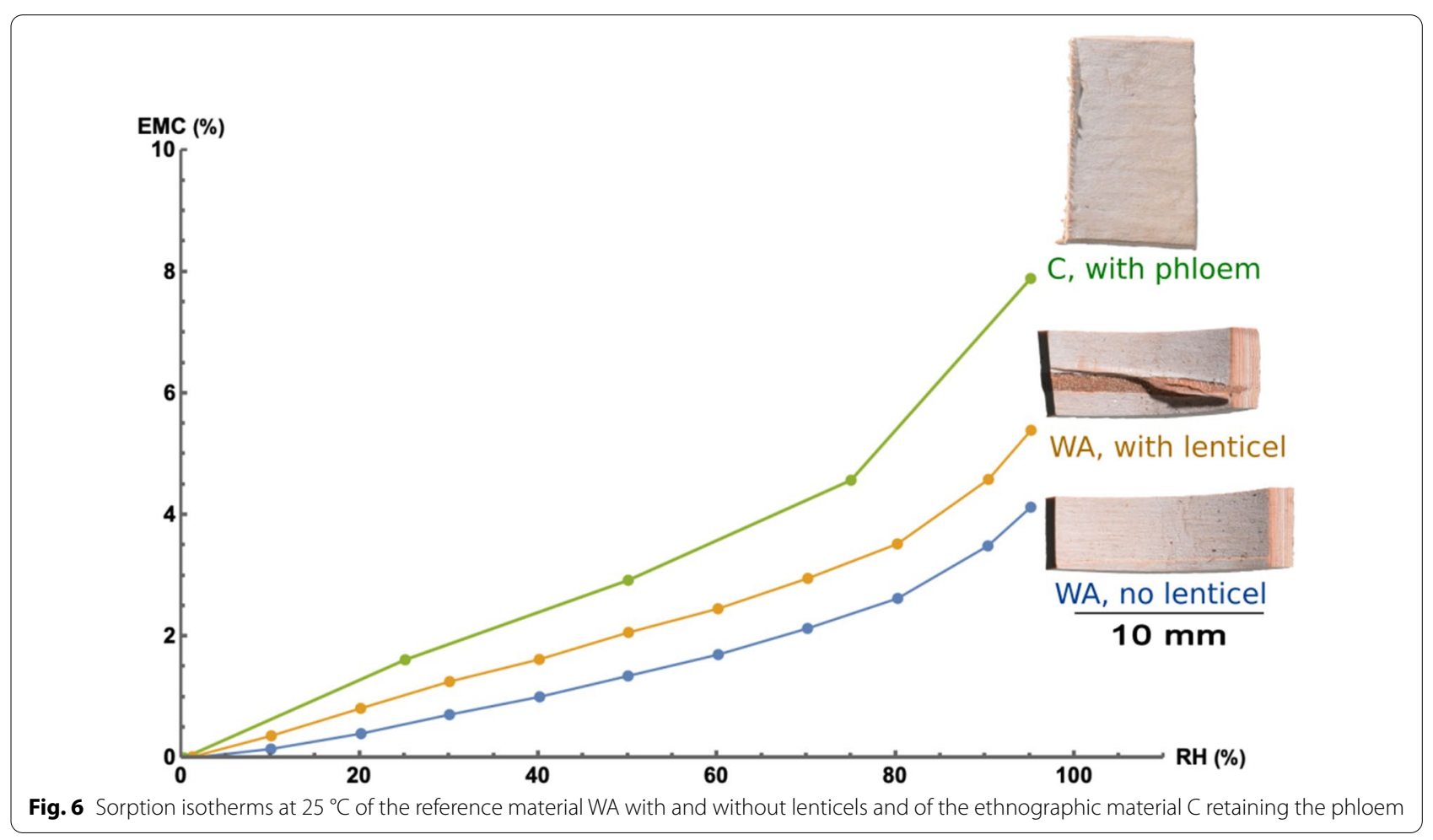




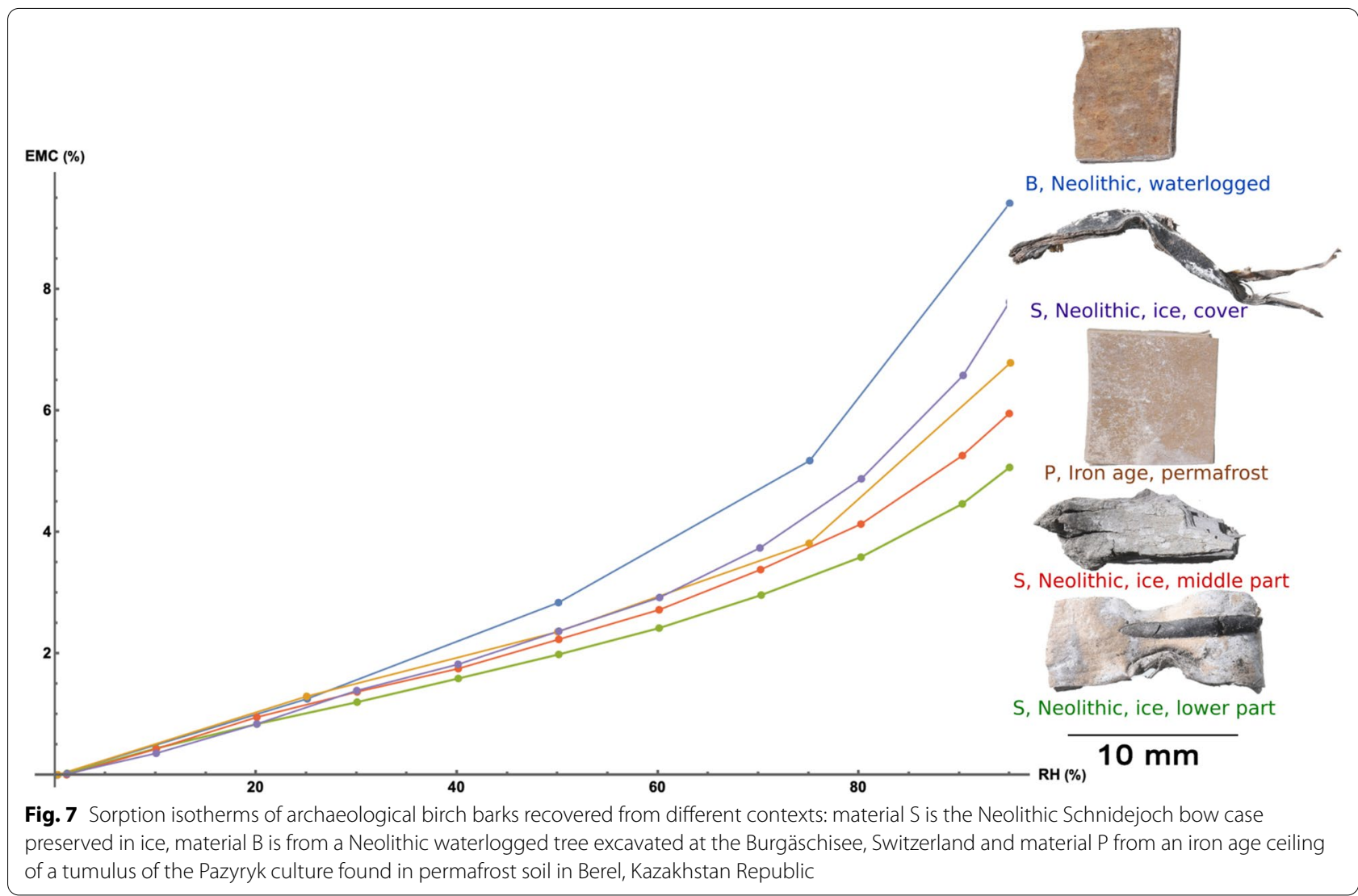

sorption isotherm at 0 and $-20{ }^{\circ} \mathrm{C}$ overlapped with the sorption isotherm at $25{ }^{\circ} \mathrm{C}$ for the sample taken from the lower part of the bow case (Fig. 8c). For the samples taken from the middle part, the isotherm at $-20{ }^{\circ} \mathrm{C}$ was higher and the isotherm at $0{ }^{\circ} \mathrm{C}$ either higher (sample 2, Fig. 8b) or overlapping (sample 1, Fig. 8a). In general, the sorption isotherm is expected to decrease with increasing temperature due of the increased mobility of the water molecules. At above zero temperatures this behaviour has been largely investigated for wood [40, 41], food [42] and building materials [43]. At sub-zero temperatures Jänchen and co-workers have found this trend in microorganisms [44] and minerals [45]. Our results, despite limited only to the Schnidejoch bow case, suggest that the equilibrium moisture content of archaeological birch bark depends slightly if at all on temperatures in the sub-zero range. An important question for conservators is if freezing archaeological objects cause damage due to freezing of bound water. Recent experimental and theoretic studies on the freezing of bound water in wood has concluded that all bound moisture is non-freezing [45-48]. Our practical experience with the Schnidejoch bow case, that was recovered from ice and is now stored at $-26^{\circ} \mathrm{C}$, confirm that no damage is observed as a result of freezing and de-freezing procedures.

\section{Swelling and shrinkage during humidification and drying}

Humidification (materials C, P) led to swelling, while drying (materials $C, P, B$ ) lead to a shrinkage of the outer bark. Table 2 summarizes the results of the experiments.

Swelling and shrinkage data in the radial direction (thickness of the samples) could not be obtained for material $\mathrm{P}$ as these samples were delaminated (Additional file 4). Material B was waterlogged and therefore swelling could not be measured.

For all materials swelling and shrinkage is higher in the radial direction and generally small in longitudinal and negligible in tangential direction. The waterlogged material (B) has considerable shrinkage especially in radial direction. This sample had also the highest mass loss after drying (53.3 wt\%), an indication that it contained liquid water in void spaces. The negligible dimensional changes in tangential direction of birch bark can be understood in analogy to the anatomy of wood cells arranged in the longitudinal direction. Wood is composed of elongated cells, the tracheids, oriented longitudinally. In this direction wood shrinkage is negligible. Birch bark is composed of elongated cells oriented tangentially (Figs. 1, 2) and in this direction its deformations are indeed negligible.

The increased swelling and shrinkage in radial direction can be explained by the unfolding of the radial cell 


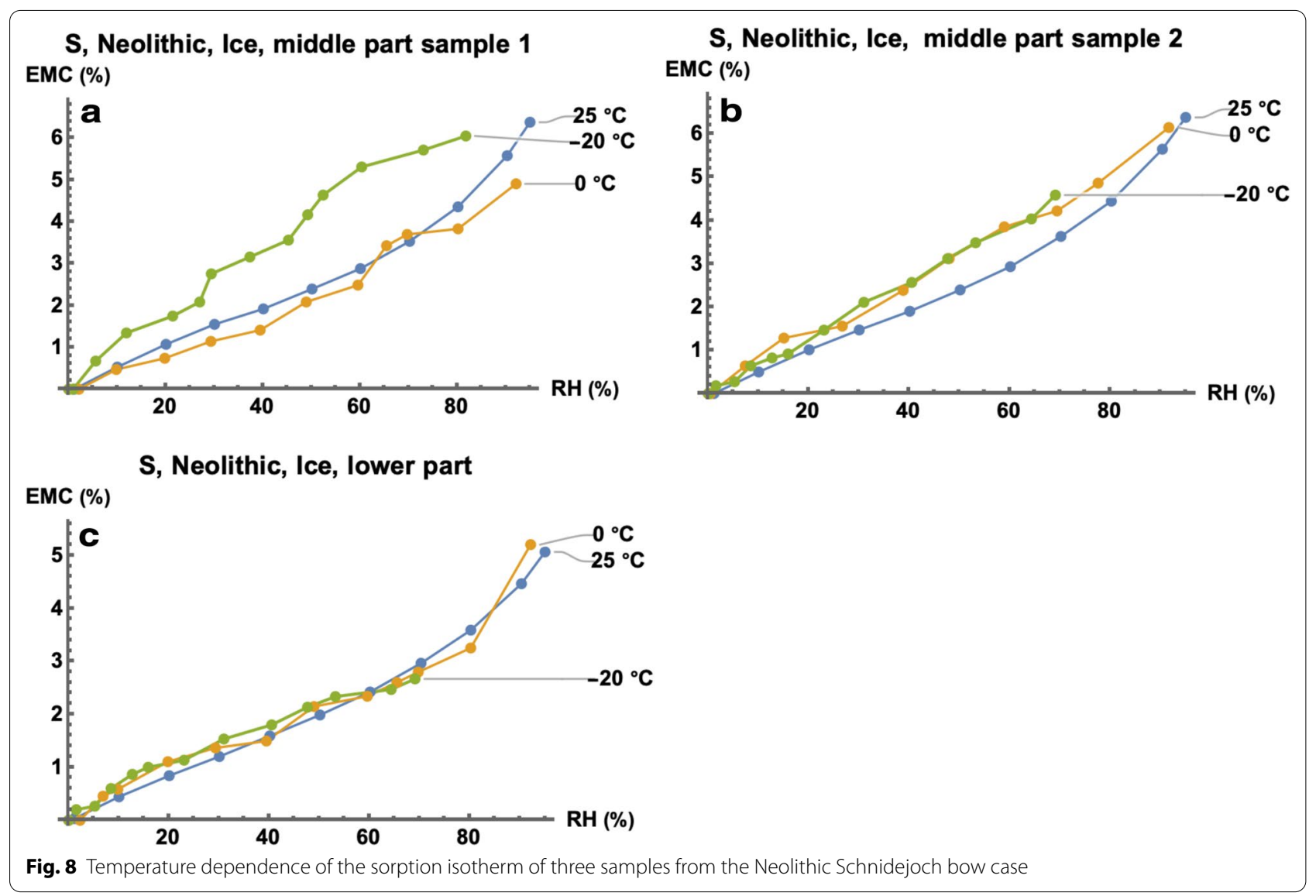

Table 2 Average swelling and shrinkage values of materials C, $P$ and B after humidification and drying

\begin{tabular}{|c|c|c|c|c|c|c|c|}
\hline \multirow[t]{2}{*}{ Sample } & \multirow[t]{2}{*}{ Value } & \multicolumn{3}{|l|}{$\%$ Swelling } & \multicolumn{3}{|c|}{ \% Shrinkage } \\
\hline & & Tangential & Longitudinal & Radial & Tangential & Longitudinal & Radial \\
\hline \multirow[t]{2}{*}{ C } & av & 0.2 & 1.4 & 2.2 & 0.3 & 2.1 & 4.8 \\
\hline & SD & 0.1 & 0.8 & 0.6 & 0.2 & 0.9 & 1.0 \\
\hline \multirow[t]{2}{*}{$P$} & av & 2.2 & 1.8 & - & 0.8 & 0.7 & - \\
\hline & SD & 0.7 & 0.4 & - & 0.2 & 0.4 & - \\
\hline \multirow[t]{2}{*}{ B } & av & - & - & - & 1.9 & 3.4 & 15.4 \\
\hline & SD & - & - & - & 1.3 & 0.2 & 3.5 \\
\hline
\end{tabular}

walls in cells with thin walls. Folded radial cell walls are expected in the outer layers of birch bark and were detected by optical microscopy in our reference material (Fig. 3). This finding is in agreement with the observations in Douglas-Fir bark [31].

\section{Deformation and mass loss during drying}

While deformations and delamination of the $\mathrm{P}$ and $\mathrm{C}$ samples took place during both adsorption and desorption, larger deformations were detected during the adsorption process $(\mathrm{C}$ and $\mathrm{P})$, accompanied by bending of the bark towards the outer layers. These movements led to delamination and deepening of tangential cracks (Fig. 9, right and Additional file 3, Additional file 4, Additional file 5). The time-lapse photography investigation allowed to monitor in details the deformation of one sample from material $\mathrm{C}$ during desorption. Surface evaporation, revealed by a colour brightening of the outer bark surface, takes place in the first two minutes of drying. In the following twenty minutes of desorption, while the moisture content decreases from 8.7 to $6.7 \%$, the sample bent slightly in the direction of the inner bark and 


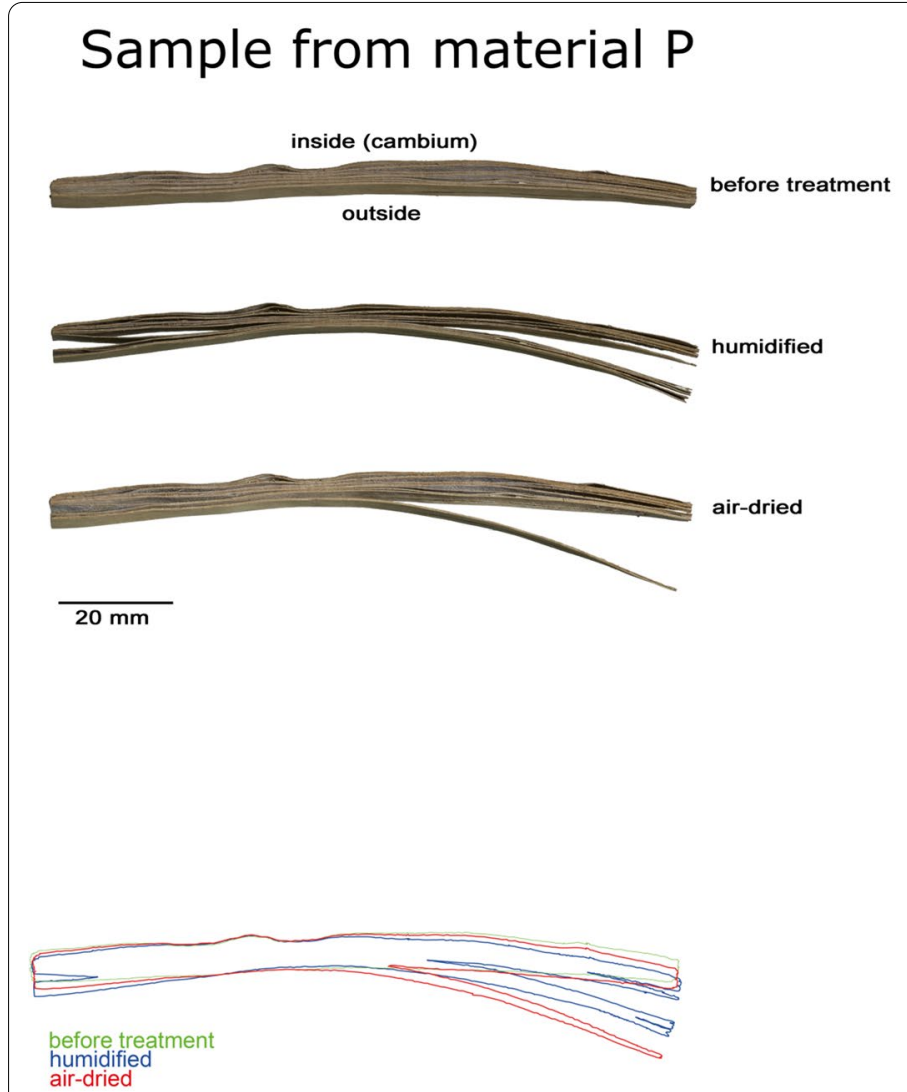

\section{Sample from material C}
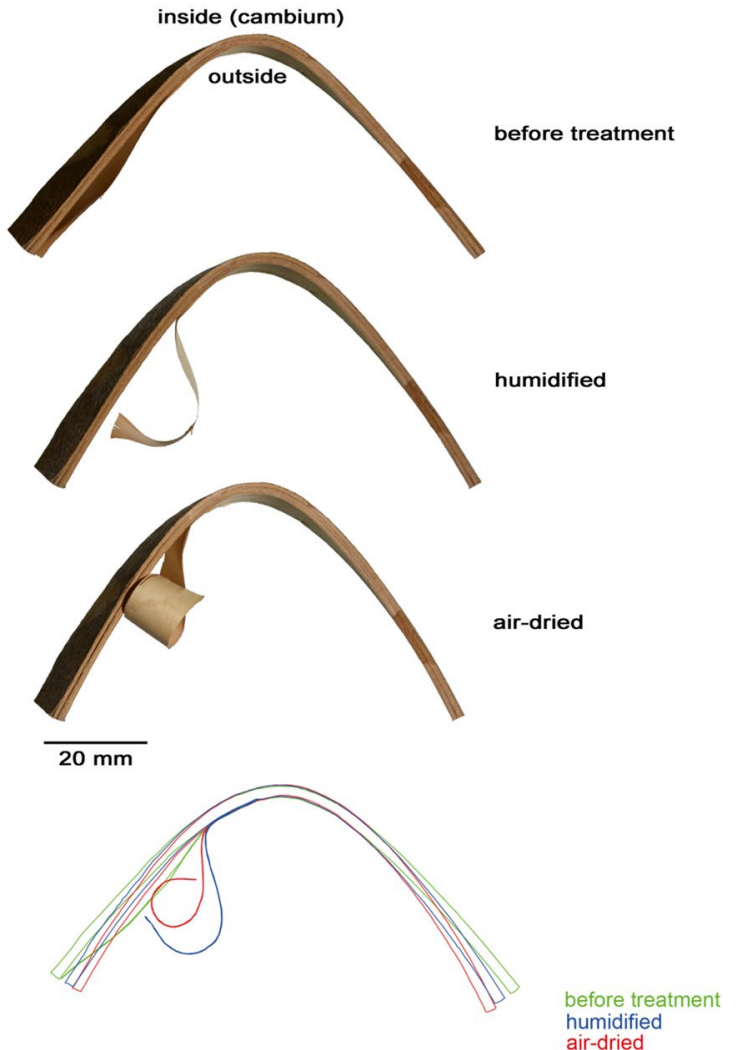

Fig. 9 Above: Deformation and delamination during humidification and drying for samples from material P, iron age from permafrost, and from material C, ethnographic. Below: Superimposed contour illustrating the warping
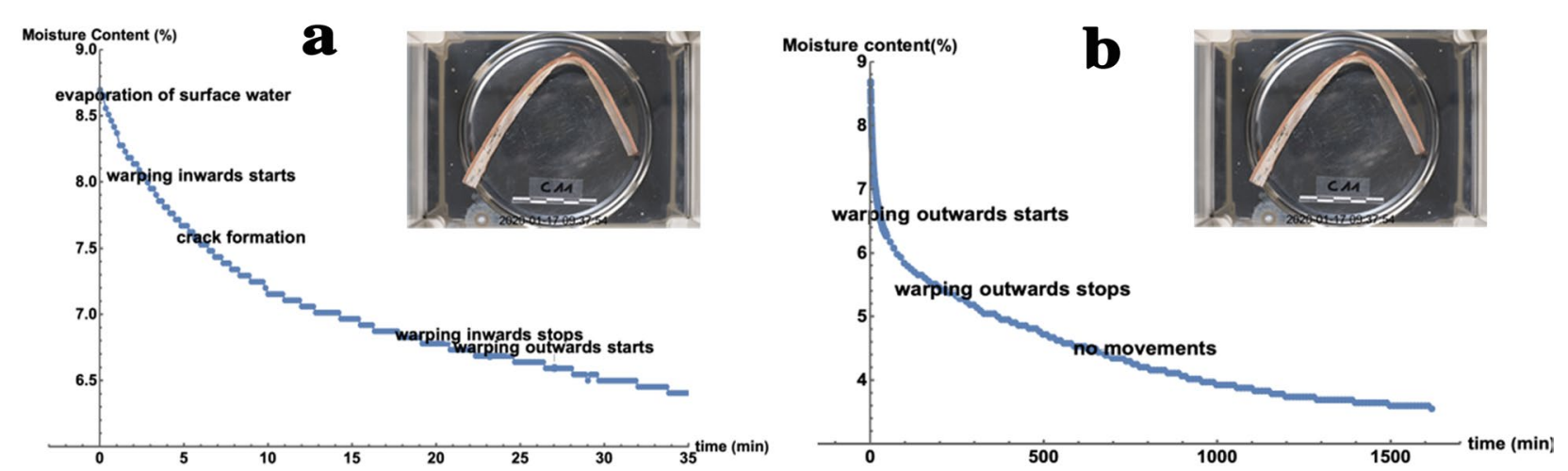

Fig. 10 Mass loss and labelled deformations detected with time-lapse photography during de-humidification from 97 to $54 \%$ RH on a sample from material C, ethnographic. a Detail of the first $35 \mathrm{~min}, \mathbf{b}$ mass loss over the whole $26 \mathrm{~h}$ period

a crack formed (Fig. 10a). A more significant movement in the direction of the outer bark dominated the process in the following three hours down to a moisture content of $4.8 \%$. After this time no movement was detected and the moisture content slowly decreased for about $24 \mathrm{~h}$ to the value of $3.5 \%$ in equilibrium with the environment at $50 \%$ RH (Fig. 10b and Additional file 6). 
The desorption kinetics depend on the geometry of the sample, on the $\mathrm{RH}$ and on the presence of ventilation. Nevertheless, it is possible to conclude that surface evaporation is a very fast process and that movements of the bark are possible at higher moisture contents, in this case corresponding to relative humidity higher than $75 \%$, as water is a flexibilization agent for birch bark. While in the time-lapse photography investigation we do not have an explanation for the inward bending of the bark, the more commonly observed outward warping is explained by the shortening of the stretched outer birch bark cells when they are plasticized at high humidity [7].

\section{Conclusions and implications for conservation measures}

This study has shown that the EMC of archaeological birch bark is generally low. The better the condition, that is the less brittle and delaminated the samples are, the lower their moisture uptake. Ice-preserved Neolithic birch bark from Schnidejoch, Switzerland, has almost the same sorption properties as unaged bark. Brittle and delaminated samples have higher moisture content, in particular waterlogged Neolithic samples had the highest moisture sorption.

The comparison among the sorption isotherms of contemporary barks found in the literature showed that the sorption behaviour does not depend on the specific Betula species. This was confirmed in our reference sample of Betula Pendula. As a consequence, there is no need in determining the species when deciding on storage conditions and treatments for birch bark objects involving water or humidity. When considering specific requirements for the storage of birch bark objects, these can be classified as mechanically stable and a broader humidity target range can be acceptable, provided it is lower than $70 \% \mathrm{RH}$. Indeed, this study shows that the EMC of brittle and delaminated archaeological birch bark sharply increases above $75 \% \mathrm{RH}$.

The investigation on samples from the Schnidejoch bow case shows that in the sub-zero range the sorption isotherm depends slightly if at all on temperature. As in wood, we expect no freezing of bound water at temperatures usually used by conservators for the long-term storage of birch bark objects.

The swelling and deformation experiments showed that water vapour can plasticize birch bark and induce a bending towards the outside of the bark. The time-lapse experiment allowed to detect movements of the bark only at high moisture contents, possibly explaining why some authors $[49,50]$ report insufficient softening through humidification. Equilibration at high humidity is a slow process as birch bark is composed of closed cells made to a large extent of hydrophobic components. Materials exposed for a long time to high humidity might develop mould. It is important for conservators to clean birch bark before humidification and mind that remains of the phloem are a good substrate for moulds as they contain polysaccharides.

Deformation and shrinkage take place during humidification and to a lesser extent also when air-drying the samples. The extent of deformation depends on the brittleness of the bark. Such deformation can lead to a tangential separation of the layers. In order to prevent damage, both humidification and drying should be performed within a supporting capsule, commonly made of a polyurethane resin impregnated fiberglass tape or of a polyester textile impregnated with a thermoplastic polyester. Dimensional changes are anisotropic, with the highest shrinkage found in the radial direction, corresponding to the thickness of the bark. These size changes do not have an impact on the appearance of the object. As a consequence, air-drying within a supporting capsule is feasible for all tested archaeological birch barks.

\section{Supplementary Information}

The online version contains supplementary material available at https://doi. org/10.1186/s40494-020-00476-y.

Additional file 1: Full scanning isotherms of contemporary samples, retaining the phloem and with or without lenticels.

Additional file 2: Full scanning isotherms of archaeological birch barks excavated from different contexts.

Additional file 3: Lateral view of B samples in waterlogged condition (above) and after drying (below).

Additional file 4: Lateral view of P samples dry (above), humidified (middle) and after drying (below).

Additional file 5: Lateral view of C samples dry (above), humidified (middle) and after drying (below).

Additional file 6: Video of time-lapse photography investigation showing the deformation of one sample from material $\mathrm{C}$ during desorption.

Additional file 7: Outer side of B samples in waterlogged condition (above) and after drying (below).

Additional file 8: Outer side of $\mathrm{P}$ samples dry (above), humidified (middle) and after drying (below).

Additional file 9: Outer side of C samples dry (above), humidified (middle) and after drying (below).

\section{Abbreviations}

wt\%: Weight percent; mm: Millimetre; ${ }^{\circ} \mathrm{C}$ : Degree Celsius; mg: Milligram; mbar: Millibar; RH: Relative humidity; EMC: Equilibrium moisture content; g: Gram; Av: Average; SD: Standard deviation.

\section{Acknowledgements}

The author would like to thank Natalia Vasilyeva and Janet Hawley for the kind donation of samples, Patricia Marxer for testing the enzymatic removal of the inner bark, the company ProUmid in the persons of Roman Kirsch and Julia Wangler for the conduction of the sorption analysis at room temperature and Thomas Herzog from the HTW Wildau for the sorption measurement with a McBain-Bakr balance. The authors also would like to thank prof. Adriano Boschetti, Archaeological Service of the Canton of Bern and prof. Albert Hafner, 
University of Bern for the support of the Project «Unfreezing History» and the anonymous reviewers whose detailed comments improved the quality of this article.

\section{Authors' contributions}

JK and GDP conceived this study. JK prepared samples and performed the swelling and shrinkage measurements and analysed the deformation and mass loss during drying. GDP interpreted sorption isotherms and prepared graphs. JK interpreted swelling/shrinkage and deformation and prepared drawings/images. JK and GDP wrote the paper.

\section{Funding}

This work was supported by the Swiss National Science Foundation (SNSF) grant and is part of the research project «Unfreezing History» (http://p3.snf.ch/ Project-159662)

\section{Availability of data and materials}

The datasets used and/or analysed during the current study are available from the corresponding author on reasonable request.

\section{Competing interests}

The authors declare that they have no competing interests.

\section{Author details}

${ }^{1}$ Bern University of the Arts, Fellerstrasse 11, 3027 Bern, Switzerland.

${ }^{2}$ Archaeological Service of the Canton Bern, Brünnenstrasse 66, 3018 Bümpliz, Switzerland.

Received: 15 August 2020 Accepted: 14 December 2020 Published online: 07 January 2021

\section{References}

1. Klügl J. How to conserve a birch bark bow case from an ice patch? In: Grant T, Cook C, editors. 12th ICOM-CC Group on Wet Organic Archaeological Materials Conference. Istanbul: ICOM-CC WOAM; 2013. p. 270-8.

2. Ward C, Giles D, Sully D, Lee JD. The conservation of a group of waterlogged neolithic bark bowls. Stud Conserv. 1996;41:241-9.

3. Gilberg RM, Grant J. The care and preservation of birch bark scrolls in museum collections. Curator. 1986;29(1):67-80.

4. Fischer A. Eine sibirische Birkenrindentasche mit Fischhauteinfassung aus dem Amurgebiet. In: Knaut M, Jeberien A, editors. Dem Objekt genähert Konservierung und Restaurierung ungewöhnlicher kulturhistorischer Materialien. Berlin: Hochschule für Technik und Wirtschaft Berlin; 2010. p. 9-37.

5. Hoffmann P. Postkarten aus Birkenrinde: wie sind sie zu entrollen Restauro: Zeitschrift für Kunsttechniken. Restaurierung Museumsfragen. 1998;104(4):246-7.

6. Dignard C, Kata S, Poulin J, Tse S. A comparison of ethanol and methanol vapour treatments for reshaping birch bark. In: Bridgland J, editor. ICOMCC 18th Triennial Conference. Copenhagen: International Council of Museums; 2017

7. Klügl J, Hafner A, Di Pietro G. On the rolling and plasticization of birch bark (submitted). In: Williams E, editor. 14th ICOM-CC Wet Organic Archaeological Materials (WOAM) Working Group Conference. UK: Portsmouth; 2019.

8. Gilberg RM. Plasticization and forming of misshapen birch-bark artifacts using solvent vapours. Stud Conserv. 1986;31(4):177-84.

9. Larsen PK, Jensen LA, Ryhl-Svendsen M, Padfield T. The microclimate within a Neolithic passage grave. In: Bridgland J, editor. ICOM-CC 18th Triennial Conference. Copenhagen: International Council of Museums; 2017. p. 109-27.

10. Orsini S, Ribechini E, Modugno F, Klügl J, Di Pietro G, Colombini MP. Micromorphological and chemical elucidation of the degradation mechanisms of birch bark archaeological artefacts. Heritage Science. 2015. https://doi. org/10.1186/s40494-015-0032-7.

11. Natalia Vasiljeva, personal communication, September 2018.

12. Grattan DW. Waterlogged Wood. In: Pearson C, editor. Conservation of marine archaeological objects. London/Boston: Butterworth; 1987. p. 55-67.
13. Barbour RJ, Rowell RM. Archaeological wood: properties, chemistry, and preservation. In: Advances in chemistry, vol 225. Washington: American Chemical Society; 1990

14. Lüttge U, Kluge M, Bauer G. Botanik. Weinheim: Wiley Verlag; 2005.

15. Kost B, der Gefäßpflanzen G. In: Kadereit JW, Körner C, Kost B, Sonnewald U, editors. Strasburger - Lehrbuch der Pflanzenwissenschaften. Springer: Heidelberg; 2014. p. 72-96.

16. Shibui H, Sano Y. Structure and formation of phellem of Betula maximowicziana. International Association of Wood Anatomists (IAWA journal). 2018;39(1):18-36. https://doi.org/10.1163/22941932-20170186.

17. Zajączkowska U. Cork. eLS. 2016;2016:1-8.

18. Pereira H. Cork: biology, production and uses. Amsterdam: Elsevier; 2007.

19. Ferreira JPA, Quilhó T, Pereira H. Characterization of Betula pendula outer bark regarding cork and phloem components at chemical and structural levels in view of biorefinery integration. J Wood Chem Technol. 2017:37(1):10-25. https://doi.org/10.1080/02773813.2016.1224248.

20. Bhat KM. Anatomy, basic density and shrinkage of birch bark. Int Assoc Wood Anat Bull. 1982:3(3/4):207-13.

21. Niklas KJ. The mechanical role of bark. Am J Bot. 1999;86(4):465-9.

22. Schönherr J, Ziegler H. Water permeability of Betula periderm. Planta. 1980;147(4):345-54

23. Chang Y-P. Anatomy of common North American pulpwood barks. New York: Technical Association of the Pulp and Paper Industry; 1954.

24. Trockenbrodt M. Qualitative Structural Changes during Bark Development in Quercus Robur, Ulmus Glabra, Populus Tremula and Betula Pendula. IAWA Journal. 1991;12(1):5-22.

25. Groh B, Hübner C, Lendzian K. Water and oxygen permeance of phellems isolated from trees: the role of waxes and lenticels. Planta. 2002:215(5):794-801.

26. Holmberg A, Wadsö L, Stenström S. Water vapor sorption and diffusivity in bark. Drying Technol. 2016;34(2):150-60. https://doi.org/10.1080/07373 937.2015.1023310.

27. Schneider A. Orientierende Vergleichsuntersuchungen über das Sorptionsverhalten mitteleuropäischer Baumrinden und Hölzer. Holz als Roh-und Werkstoff. 1978;36(6):235-9.

28. Standke W, Schneider A. Investigations on the sorption-behaviour of the inner and outer bark of different trees. Holz als Roh-und Werkstoff. 1981:39(12):489-93.

29. Wilhelmsen G. Bark-water relationships: III. Moisture content and water absorption capacity in bark of Norway spruce, Scots pine and birch. Tidsskr Skogbruk. 1970;78(4):403-10.

30. Kajita H. Juhi-mizukei no sogo sayo (The bark-water relationship). Zairyo J Soci Mater Sci. 1975;264(24):862-6.

31. Krahmer RL, Wellons JD. Some anatomical and chemical characteristics of Douglas-Fir cork. Wood Science. 1973;6:97-105.

32. Rosa ME, Fortes MA. Water absorption by cork. Wood Fiber Sci. 1993:25(4):339-48.

33. Beck BC. An introduction to plant structure and development. Cambridge: Cambridge University Press; 2010.

34. Orgell WH. The isolation of plant cuticle with pectic enzymes. Plant Physiol. 1955:30:78-80.

35. Schreiber L, Schönherr J. Water and solute permeability of plant cuticles: measurement and data analysis. Berlin: Springer; 2009.

36. Murr A, Lackner R. Analysis on the influence of grain size and grain layer thickness on the sorption kinetics of grained wood at low relative humidity with the use of water vapour sorption experiments. Wood Sci Technol. 2018;52(3):753-76. https://doi.org/10.1007/s00226-018-1003-4.

37. McBain JW, Bakr AM. A new sorption balance 1. J Am Chem Soc 1926;48(3):690-5

38. Fredriksson $M$, Thybring EE. Scanning or desorption isotherms? Characterising sorption hysteresis of wood Cellulose. 2018;25(8):4477-85. https ://doi.org/10.1007/s10570-018-1898-9.

39. Standke W, Schneider A. Untersuchungen über das Sorptionsverhalten des Bast- und Borkeanteils verschiedener Baumrinden. Holz als Roh- und Werkstoff (European journal of wood and wood products). 1981;39:489-93.

40. Glass S, Zelinka S. Chapter 4 Moisture relations and physical properties of wood. In: Wood handbook-Wood as an engineering material. U.S. Department of Agriculture, Forest Service; 2010. p. 4.1-4.19 
41. Esteban LG, de Palacios P, García Fernández F, García-Amorena I. Effects of burial of Quercus spp. wood aged $5910 \pm 250$ BP on sorption and thermodynamic properties. Int Biodeterior Biodegrad. 2010;64(5):371-7. https://doi.org/10.1016/j.ibiod.2010.01.010.

42. Staudt PB, Kechinski CF, Tessaro IC, Marczak LDF, Soares RD, Cardozo NSM. A new method for predicting sorption isotherms at different temperatures using the BET model. J Food Eng. 2013;114:139-45.

43. Karoglou M, Moropoulou A, Maroulis ZB, Krokida MK. Water sorption isotherms of some building materials. Drying Technol. 2005;23:289-303.

44. Jänchen J, Bauermeister A, Feyh N, de Vera J-P, Rettberg P, Flemming $\mathrm{H}-\mathrm{C}$, et al. Water retention of selected microorganisms and Martian soil simulants under close to Martian environmental conditions. Planet Space Sci. 2014;98:163-8. https://doi.org/10.1016/j. pss.2013.06.011.

45. Jänchen J, Bish DL, Mohlmann DTF, Stach H. Investigation of the water sorption properties of Mars-relevant micro- and mesoporous minerals. Icarus. 2006;180(2):353-8. https://doi.org/10.1016/j.icarus.2005.10.010.
46. Zelinka SL, Lambrecht MJ, Glass SV, Wiedenhoeft AC, Yelle DJ. Examination of water phase transitions in Loblolly pine and cell wall components by differential scanning calorimetry. Thermochim Acta. 2012;533:39-45. https://doi.org/10.1016/j.tca.2012.01.015.

47. Engelund ET, Thygesen LG, Svensson S, Hill CAS. A critical discussion of the physics of wood-water interactions. Wood Sci Technol. 2013:47(1):141-61. https://doi.org/10.1007/s00226-012-0514-7.

48. Willems W. Equilibrium thermodynamics of wood moisture revisited: presentation of a simplified theory. Holzforschung. 2016;70:963-70. https ://doi.org/10.1515/hf-2015-0251.

49. Johnston $\mathrm{N}$ : Humidity, it's all-relative: humidification treatment of a birch bark canoe model, part 2. (2015). Accessed 10 Oct 2019

50. Maitland C. Learning to conserve a Kashmiri birch bark manuscript. Book Pap Group Annu. 2016:35:49-60.

\section{Publisher's Note}

Springer Nature remains neutral with regard to jurisdictional claims in published maps and institutional affiliations.

\section{Submit your manuscript to a SpringerOpen ${ }^{\circ}$ journal and benefit from:}

- Convenient online submission

- Rigorous peer review

- Open access: articles freely available online

- High visibility within the field

- Retaining the copyright to your article

Submit your next manuscript at $\boldsymbol{\nabla}$ springeropen.com 